PEDAGÓGUSKÉPZÉS, 10-11 (39-40), 2012-2013. 229-232.

\title{
DigitÁlis PEDAGóguS KONFERENCIA 2012
}

\author{
Petry ANNAMÁria \\ az Eötvös Loránd Tudományegyetem Pedagógiai és Pszichológiai Karának \\ doktorandusz hallgatója \\ petry.annamaria@gmail.com
}

Nagy érdeklődés kísérte neveléstudományi körökben a 2012. május 26-án megtartott Digitális pedagógus c. konferenciát. Idén ez már a második összejövetele azoknak a szakembereknek, tanároknak, érdeklődőknek, akiket foglalkoztatnak korunk társadalmában, oktatásában végbemenő tendenciák (Digitális nemzedék konferencia 2012. február 11. ELTE PPK Budapest).

Perjés István dékánhelyettes megnyitó beszédében a mai kort Kolumbusz 1492-es új világ felfedezéséhez hasonlította, ahol szintén bennszülöttek voltak, akik a bevándorlóknak adtak térképet, $\mathrm{s}$ várakoztak - (nem tudván, mi vár még rájuk) ebben a szép, új világban, hogy felfedezzék őket. A digitális bennszülöttek világa természetesen másképpen új világ, mint amit Kolumbusz talált, de fontos a párhuzamban a megismerés szükségessége, hiszen ők a birtokosai egy óriási, a bevándorlók számára nem teljességében átlátható világnak.

Szekszárdi Júlia, az Osztályfőnökök Országos Szakmai Egyesületének Elnöke az egyesület új feladatairól beszélt, mennyiben tudnak megfelelni az új kor kihívásainak. Majd Komenczi Bertalan, az Esterházy Főiskola docense szólalt fel. Az iskolákban müködő elektronikus tanulói környezetről beszélt - felhívva a figyelmet a www.ektf.hu/www.ektfkbert oldalra, ahol hasznos információkhoz juthatunk a témát illetően. Az elme és a kultúra kapcsolatáról szólt Bruner alapján, rámutatva: ha a két halmaz (emberi elme - gyermeki kultúra) metszetének tekintjük az oktatást, akkor a mai kor egyik legégetőbb kérdése: megtalálni azon technológiák halmazát, mely jelenleg hiányzik, s elengedhetetlen a sikeres oktatás érdekében. Igen tartalmas, színvonalas előadásában Marshall Mcluhan médiaelméletéről, az őt követő Neil Postman, valamint Joshua Meyrowitz médiaelméletéről beszélt. Külön kitért mondandójában a neveléstudományi körökben jól ismert TED oktatási paradigmára, majd az ún, ,társas optimisták"-ról beszélt Pléh Csaba A természet és a lélek (Osiris Kiadó, 2003) c. könyve alapján. Majd a „társadalmi pesszimisták”-ról, „biológiai optimisták"-ról esett szó - ezzel zárva kiváló előadását Komenczi Bertalan. Az előadás ppt-je megtalálható a http://www.slideshare.net/digipedkonf/komenczibertalan-a-digitalis-pedagogus-elmeleti-megkozelitesek-fogalommeghatarozasok internetes honlapon. 
Ollé János - ELTE PPK - A digitális állampolgár (digital citizenship) - pedagógus kompetenciák müködés közben címmel tartott előadást. A digitális tanár jellemzői között említette a digitális eszközök tudatos használatát, a produktív tervezést (létrehozni valamit), a digitális kultúrában való aktív részvételt és annak aktív formálását, a folyamatos, cselekvő online közösségi tevékenységet. Az előadó szerint a korszerü, digitális tanárnak meg kell tanítania a gyerekeket szelektálni az információ özönben, a digitális produktivitás, a digitális lábnyomok hagyása (digitális identitás és e-portfólió létrehozás), a tudatos tartalommegosztás (pl. a facebookon), a digitális közéleti szereplés (web 2-es alkalmazások - pl. konferenciát élőben megosztani) - ez lenne a digitális tanár feladata. Elmondta Ollé János, hogy az ISTE (International Sociaty for Technology) 2000-ben és 2008-ban ismertette a hatékony digitális tanár standardjait, teljesítményindikátorait. Ezek között szerepel a tanulói kreativitás, a tanuló inspirálása, a személyre szabott tanulói aktivitás, a tanári személyes példa fontossága, a szükebb és tágabb környezetben való aktivitás. Zárásként a digitális állampolgárságról mint személyes példáról beszélt. A tanárnak etikailag, jogilag helyes utat kell mutatnia, ellensúlyoznia kell a tanulók impulzív és szabad forrásfelhasználást, törekedni kell arra, hogy megmaradjon az adaptivitás, differenciálás, példát kell mutatnia az online kooperációra, közösségfejlesztésre.

A következő felszólaló Knausz Imre docens, a Miskolci Egyetem BTK Tanárképző Intézetének igazgatója. Előadásának a Hálóba gabalyodva címet adta. Az oktatásban a hagyományos mủveltség közvetítését a giroszkóphoz (pörgettyühöz) hasonlította, melyben a létrehozott forgás egy sajátos stabilitást hoz létre, mint ahogy a müveltség is hasonló szerepet játszik az emberi személyiségben. Történelmi viszszatekintésében rámutatott, hogy a 15-20. századig a müveltség belső stabilitást, gerincet, tartást adott, értékrenddel ruházta fel az embereket. Példának hozta fel a Caesarok klubja c. filmet, melyben a pedagógia két fontos feladatát emelte ki: a tudás, oktatás, ill. az erkölcs, nevelés kettősségének sajátos formában való bemutatását emelte ki. Majd David Riesman (1909-2002) A magányos tömeg c. könyvére utalt, hogy mennyire sokkolta az 1950-es években a pedagógia világát. Az ott kifejtett RADAR-elmélet - ,a posztmodern embernek nem belső iránytüje van, hanem belső radarja" - jól mutatja, mit változott a világ. Fontos lett, hogy mit mondanak az ember számára fontos mások, a trendiség, a „mások uralma”, az empátia kérdésének sajátos megjelenése (elvek vagy érzelmek egymás mellett kell müködjenek). Az önmagukról írt tudósítások (facebook) és az arra kapott információk felértékelődése. Érdekes gondolata volt az előadónak a „mai iskola a facebook foglya, a jelen foglya" metafora, melyet jól érzékeltet a facebook példája, ahonnan pillanatok alatt eltünnek 5 perce feltett információk. Lehetséges, hogy olyan korban élünk, ahol a kommunikációban előbb megszerkesztett információkra később nincs szükség? Vagy elfelejtődnek, s ez az agyunk részének, a hippokampusz müködésének a megváltozására utal? Miért is a hálóba gabalyodva költői kép az előadás címe? Az iskola helyzetét érzékelteti velünk a szerző. Mekkora a kulturális szakadék tanár és 
diák között? Mennyire szabad vagy kell a mai kor emberének engedni beszippantani magát az új technika csapdáiba? Tanár maradok-e a facebookon? Ezek a mai kor kérdései. Végül az előadó összegzése a következő volt: meg kell érteni az ifjúságot, ,értően meghallgatni a másikat, és megmutatni magamat”. Ehhez viszont radikálisan át kellene alakulnia az iskolának.

Racskó Péter a Nemzeti Tankönyvkiadó igazgatója következett. A Sanoma Compania keretein belül lezajlott kutatás eredményéről számolt be. A nemzetközi kutatás a magyarországi iskolák helyzetére is rámutatott az európai államokkal való összehasonlítás során. Európához viszonyítva az iskolai költségvetés 1-2\%-át használjuk fel IKT-eszközök vásárlására. Ugyanakkor felmerül a kérdés: Mikor segítünk a pedagógusnak? „A digitális tananyag fontos-e, ugyanis a tanár így nem tudja azt csinálni, amiért pedagógus lett...” Az előadó ezután egy érdekes eszmefuttatást tett közzé: mi a különbség a digitális tanár és a hagyományos tanár között. Az e-pedagógus a teljes munkaidő 5\%-ában tananyagot készít elö, 75\% egyéb munkája van és 20\%-ban tanít, míg a hagyományos tanár 50\%-ban tanít, 25\%-ban készül és $25 \%$ egyéb elfoglaltsága van. Melyiket kellene választani?... A tendenciák szerint egyre nagyobb teret fog nyerni az elektronikus tananyag. Ám vannak még tennivalóink: a nyugati országokban a papír alapú, fizetős tananyag (Pf) helyét átvette az elektronikus, ingyenes (E-0), majd a Pf és Ef (elektronikus, pénzbe kerülö) párhuzamosan elterjedt, végül Ef és Pf - tehát bár fizetni kellett érte, de a papír alapú tananyag helyét átvette az elektronikus, fizetős segédeszközök. Magyarországon mi most a Pf, E-0 állapotnál tartunk, azaz dominálnak a fizetős, papír alapú tananyagok, a nem fizetős, elektronikus tananyagokkal szemben. A tanári munkafolyamatok szemléltetésére egyre több eszköz áll rendelkezésre: kérdőívek, prezi - a ppt helyett stb. Az előadó szerint az elektronikus tananyagok elterjedésének legnagyobb gátja az, hogy Magyarországon a papír alapú tankönyvben bíznak a legjobban a pedagógusok, s lehet, hogy ez összefüggésbe hozható a pedagógusok helyzetével, rezignáltságuk magas szintjével.

Az előadásokat az ebédszünet után kerekasztal beszélgetés követte, melyet Füzfa Balázs irodalomtörténész, a Nyugat-Magyarországi Egyetem docense vezetett.

Kerber Zoltán oktatáskutató, az OFI munkatársa beszélt az X, Y, Z generáció sajátosságairól, majd az X generációba tartozó mai tanárnemzedék nehéz helyzetéről szólt. Leszögezte, hogy az idősebb tanári nemzedéknek kell igazodnia a fiatalabb tanulói korosztályhoz - más típusú tananyaggal és módszerrel kell tanítani őket, hogy az irodalomtanítás ne haljon meg.

Sirató Ildikó adjunktus, az Országos Széchényi Könyvtár Színháztörténeti Tár osztályvezetője az irodalomtanítás múvészetjellegét emelte ki. „Tiltakozom az irodalom eltárgyiasítása ellen." - mondta érzelmektől nem mentes beszédében. A Mit akarunk átmenteni a hagyományokból? kérdésre a következő válaszokat adta: a tudásanyagok segítsék a fiatalok világban való elhelyezkedését vizuális, auditív, IKT-esz- 
közök, új módszerek segítségével. A digitális tartalomképzés megjelenésével a tanároknak is új lehetőség nyílik kreativitásuk megmutatására, fejlesztésére.

Szávai Ilona a Pont Kiadó igazgatója kérdésére: Mit tegyünk a digitális iskolatáskába? maga adta meg a választ. A motiváció kérdésére helyezte a hangsúlyt, $\mathrm{s}$ a közönség figyelmébe ajánlotta Az olvasás védelmében - olvasáskutatási tanulmányok c. kiadványukat.

Sz. Tóth Gyula tanár, oktatási szakértő véleménye szerint a digitális galaxison az iskola máshogy müködik, sporthasonlattal élve: a gyerek gyorsan, egy vizuális világban vívni szeretne, de ezt az iskola visszafogja. Követendő példaként említette hegymászó Eröss Zsolt és a kenus Rakonczay Gábor esetét, akik maguk tervezték expedíciójukat, maguk cipelték a csomagjaikat és kivitelezték terveiket. A tanulókkal is ezt kéne megértetni végre, hogy ők cipelik az iskolatáskát, ők élnek az életben, ők tanulnak az iskolában. Nem az a mai oktatás célja szerinte, hogy szemléltessünk, hanem cselekedtessük a tanulókat, leültessük őket egy olyan terembe, ,,ahol a gyerek számítógép közelben maga keresheti meg az aktuális tananyaghoz kapcsolódó dolgokat”. Saját felfedezésként élje meg a tanulást a digitális eszközök segítségével.

Végül Varga Richard hallgató kapott szót, a Nyugat-Magyarországi Egyetem hallgatója. Állítása szerint otthonról az iskolába menni a tanulóknak egy időutazás 50 évvel visszafele. A tanárok szerepét a hallgatókkal való ideális kommunikációban a következő mondattal jellemezte: „Nem vagyok idegen a veled való kommunikációban.” S szeretné, ha az ilyen tanári mondatok, mint „Ez nem az én világom." - eltünnének az oktatásból. Felhívta a figyelmet arra, hogy maga is tapasztalja az agyi kompetenciák változását a televízió, internet hatására, s az élményszerủ tanítás, az IKT-eszközök használatára ösztönözte a kollégákat. Az utolsó szó jogán körkérdésre a beszélgetés résztvevői röviden összegezték véleményüket a témában.

Elmondhatjuk, hogy egy jól szervezett, kiváló konferencián vettünk részt, láthattuk, hogy az előadók és a közönség is tudatában van felelősségének a ma nemzedékének tanításában.

Az ELTE PPK aulája csordultig megtelt a konferenciára, a siker új konferenciák szervezésére buzdít mindnyájunkat. 